\title{
鋼構造ブレース付き平面骨組モデルのブレース配置に関する最適設計解特性 CHARACTERISTICS OF OPTIMAL DESIGNS OF PLANE BRACED STEEL FRAME MODELS WITH RESPECT TO BRACE PLACEMENT
}

\author{
李 有 震*, 五十子 幸樹**, 吉 富 信 太***, 上谷宏二**** \\ Yujin LEE, Kohju IKAGO, Shinta YOSHITOMI \\ and Koji UETANI
}

\begin{abstract}
In most cases, it's quite difficult for structural designers to perform many case studies when they plan a layout of earthquake resistant elements in a preliminary architectural design. So it would be helpful for them to know the characteristics of optimum designs, which can be regarded as standard design, with respect to the changes of numbers or layouts of earthquake resistant elements.

In this paper we present characteristics of optimum designs of steel plane frames with respect to layouts of multi-story braces through an examination of optimum designs by examining optimum design solutions of multi-story frames with various layouts of braces.
\end{abstract}

\section{Keywords : Minimum weight design, Optimal design, Braced steel frame, Structural planning, Decision making, Brace placement \\ 最小重量設計，最適設計，鋼構造ブレース付き骨組，構造計画，意思決定，ブレース配置}

\section{1. はじめに}

建築構造物の設計の初期段階において、構造設計者は構造部材の 大まかな配置や断面部材の大きさを決定する。この段階の決定事項 は、後の詳細設計の中で若干調整されることもあるが、建築物の空 間構成や建築計画の枠組みを決定してしまうので、建築計画段階に おいて重要な意味を持っている。一般にこの段階では建物の平面計 画が流動的であるため、詳細な構造解析のモデルを作成して構造計 画の妥当性を検証することは困難であり、構造計画は構造設計者の 経験に基づく判断に頼らざるを得ない場合が多い。一方、近年設計 者にはこれまで以上の説明責任が求められているため、設計者の判 断を裏付ける論理的根拠が求められている。

これまでに、設計の論理化に繋がる研究は多数なされており、論 理的構造設計手法を実務に適用するための様々な工夫や提案も行な われている 1) 7)。しかしながら、それらの研究の多くは、部材の配 置が指定された骨組に対して各部材の断面を決定するという、実務 設計の断面設計の段階を対象としているため、個別の条件の下での 部材断面の最適解は得られるものの、架構におけるブレースの配置 や設計条件が不確定な構造計画段階で参考となる情報を直接知るこ

\section{とは出来ない。}

前述した建築設計の現状に対して、著者らは最適設計手法や構造 解析問題の逆問題型定式化により得られる設計解を建築構造物の 「標準的な設計」と位置づけた上で、その一般的性質を抽出して論 じることにより設計の論理化を促進することが出来ると考えている。 例えば、設計与条件の変化に対する設計解の変化の特性が明らかに なれば、設計者は構造計画段階において、建築計画上の要請などに 配慮しながら合理的な判断をすることが出来るであろう。そのため に、著者らは建築構造物の最適設計手法により得られた標準的な設 計解の性質を分析、抽出して設計与条件の変化に対する設計解の変 化等を系統的に示すことで、構造計画を行う設計者に有益な汎用性 の高い情報を提示する方法論を提案している。具体的には、純ラー メン骨組を対象として平面骨組最適解の特性を抽出し、その特性を 用いることで、任意のスパン数やスパン長を有する骨組みの最適解 鋼材量を、少ない計算コストでかつ実用上十分な精度で予測可能な 近似予測モデルを提案している 8) 10)。また、既報 ${ }^{11)}$ においては、鋼 構造ブレース付き骨組モデルについてスパン数やスパン長の変化に 対する最適解の変化を調べ、最適解が与える鋼材量のスパン数及び

\footnotetext{
$*$ 京都大学工学研究科建築学専攻 研究員 $\cdot$ 博士 $($ 工学 $)$

*** (侏)日建設計構造設計室 主管・博士 (工学)

*** 京都大学工学研究科都市環境工学専攻 助教・博士 (工学)

**** 京都大学工学研究科建築学専攻 教授. 工博
}

Researcher, Dept. of Architecture and Architectural Systems, Graduate School of Eng., Kyoto University, Dr. Eng.

Senior Eng., Structural Dept., NIKKEN SEKKEI Ltd., Dr. Eng.

Kyoto University, Dr. Eng.

Prof., Dept. of Architecture and Architectural Systems, Graduate School of Eng., Kyoto University, Dr. Eng. 
スパン長に対する簡易予測式を提案した。これらの研究は、鋼構造 骨組に対する耐震要素の配置計画において構造設計者が、建築計画 上の要請、耐震性能、構造コス卜などの情報と併せて合理的な判断 を行なうための有益な情報を与えるものである。

本論文では、標準的な設計解から耐震要素配置に関する実務設計 上有益な情報を抽出することを目的として、基準法上の規定や実務 設計で標準的に用いられている諸条件やモデル化を採用した鋼構造 ブレース付き骨組を対象として、ブレース配置の変化が最適解の総 鋼材量に及ぼす影響について検討寸る。具体的には、平面骨組モデ ルを用いて 1 スパンの連層ブレースまたは、複数スパンの連層ブレ ースを連結したブレース群の骨組内への配置が設計解へ与える影響 に着目した検討を行なう。

\section{2. 最適設計問題}

\section{1 対象モデル及び荷重の設定}

本論文では，立体骨組モデルを平面骨組モデルに分解して分析す るため，立体骨組モデルは平面図上で直交する軸上に部材が配置さ れているような一般的な整形モデルとし、平面モデルは立体モデル から取り出したものとする。平面モデルに作用する荷重は、想定す る平面骨組が負担寸る床面積に応じて図 1 のように設定する。鉛直 荷重は床面積の幅 $(D)$ に比例し、水平荷重は床面積の幅 $(D)$ と長さ $(L)$ に比例する。

・長期荷重：床、梁、ブレース、柱の自重を含む単位面積当りの床 重量を大梁に等分布荷重として与える。

- 短期荷重 : 1 次設計用地震荷重として $A_{i}$ 分布から算定した水平荷 重を各層重心に作用させる。

$\cdot 2$ 次設計用地震荷重 : 2 次設計用地震荷重として必要保有水平耐力 $Q_{u n}$ と等価な層水平力を $P_{u n}$ とし、骨組の荷重増分解析は荷重係数 $\lambda$ を乗じた $\lambda P_{u n}$ を漸増載荷して行なう。保有水平耐力 $Q_{u}$ は最大層 間変形角が指定值となるときに各層が負担する層せん断力として 評価する。

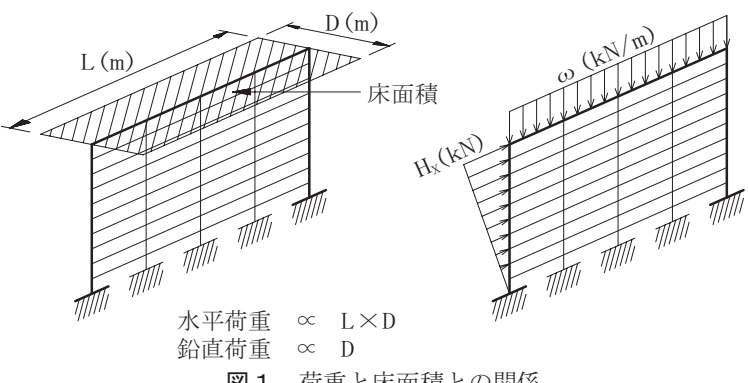

図 1 荷重と床面積との関係

\section{2 鋼材量最小化問題の設定}

コストは、単に鋼材量に比例するわけではなく、製作・施工に関 わる様々な制約条件の影響を受ける。一方、単位床面積あたりの鋼 材質量 $\left(\mathrm{kg} / \mathrm{m}^{2}\right)$ は実務設計者によって判断基準の指標となる場合が多 く、重要な一次情報である。本論では、鋼材質量と一対一に対応す る鋼材総体積を最小化する最適化問題を扱う。この場合の最適化問 題は式(1)のように定式化できる。
Find
$A_{j}\left(j=1, N_{v}\right)$

To minimize $\quad f\left(A_{j}\right)=\sum_{j=1}^{N_{m}}\left(A_{j} \times L_{j}\right)$

Subject to $\quad \underline{A}_{j} \leqq A_{j} \leqq \bar{A}_{j} \quad\left(j=1, N_{v}\right)$ [断面積上下限制約] $<1$ 次短期設計用荷重時 $>\delta_{j} / h_{j} \leqq R\left(j=1, N_{f}\right)$ [層間変形角制約]

$$
\left|\frac{M}{Z f_{b s}}\right|+\left|\frac{N}{A f_{c s}}\right| \leqq 1
$$

[応力制約]

$<1$ 次長期設計用荷重時 $>d / l_{b} \leqq 1 / 300$

[梁中央たわみ制約]

$$
\left|\frac{M}{Z f_{b l}}\right|+\left|\frac{N}{A f_{c l}}\right| \leqq 1
$$

[応力制約]

$<2$ 次設計用荷重時 $>\quad Q_{u n} \leqq Q_{u}$

[保有水平耐力制約]

\begin{tabular}{|c|c|}
\hline$N_{v}$ : 設計変数の数 & $N_{m}$ : 総部材数 \\
\hline$h_{j}:$ 各層の階高 & $N_{f}$ : 層数 \\
\hline$f_{b s}:$ 許容曲げ応力度（短期） & $f_{c s}$ : 許容圧縮応力度（短期） \\
\hline$f_{b l}$ : 許容曲げ応力度（長期） & $f_{c l}$ : 許容圧縮応力度 (長期) \\
\hline$L_{j}$ : 各部材の長さ & $d$ : たわみ \\
\hline : スパン長 & $Q_{u n}$ : 必要保有水平耐力 \\
\hline
\end{tabular}

一記号の説明

$Q_{u}$ : 最大層間変形角が $1 / 75$ のときの各層の層せん断力

本論では、柱脚の引き抜き制約や，ブレース水平力分担率制約を 考慮しない最も標準的な問題を扱い, ブレース付き骨組の最適解の 基本的な性質の抽出を目的とする。柱脚の引き抜き制約や、ブレー ス水平力分担率制約を付加することが最適解にどのような影響を及 ぼすかについては報を改めて論じる。

\section{3. ブレース付き平面骨組モデルの最適解特性}

既報 ${ }^{11)}$ では、鋼構造ブレース付き平面骨組モデルの基本特性及び、 スパン数・スパン長の変化による最適解の特性について述べた。本 論文では、骨組スパン数・ブレース設置スパン数、ブレースの配置 方法をパラメータとして変動させた場合の最適解を相互比較するこ とで、ブレースの配置による最適解特性の抽出を試みる。既報と同 椂に階数や階高は、敷地の条件から計画の初期段階で決定される場 合が多いためにパラメータとして扱わず指定するものとする。

\section{<設計条件>}

・ 1 階の柱脚は固定し、各階とも剛床を仮定する。

・ブレースは連層 X 型配置とし、引張ブレース、材端ピン接合とす る。ブレースについては鋼棒, 等辺山形鋼, 溝形鋼, $\mathrm{H}$ 形鋼などの 任意の形鋼を想定するが，断面積のみを設計変数とする。

・弾塑性解析は、軸力と曲げの相関を無視した完全塑性ヒンジを弾 性部材の両端に配置した弾塑性梁有限要素を用い、変位増分法に よって行った。

・制約条件として以下の条件を設定する。

(1)断面積上下限值制約 : 梁 : $2.635 \times 10^{3} \leqq A \leqq 3.874 \times 10^{4}\left(\mathrm{~mm}^{2}\right)$

$$
\begin{aligned}
& \text { 柱 : } 4.563 \times 10^{3} \leqq A \leqq 1.067 \times 10^{5}\left(\mathrm{~mm}^{2}\right) \\
& \text { ブレース : } 3.801 \times 10^{2} \leqq A\left(\mathrm{~mm}^{2}\right)
\end{aligned}
$$

(ブレースに多くの水平力を分担させるためにブレースの上限值を設けない) (2)層間変形角制約 : $|R| \leqq 1 / 200$

(3)保有水平耐力制約 $\left(Q_{u} \geq Q_{u n}=D_{s} F_{e s} Q_{d}\right): D_{s}=0.3$ 、各層の形状 特性係数 $F_{e s}=1.0$ 、地震力によって各層に生じる水平力 $Q_{d}$ は 1 次設計用荷重と同じ分布形と仮定する。 $Q_{u}$ は最大層間変形角が 1/75のときに各層が負担する層せん断力とする。 
・モデルの対称性のみ考慮した部材のグルーピングを行う。

・各部材の初期断面は、柱・梁断面については断面積上下限值制約 のうち上限值を、ブレースは指定值 $\left(6.353 \times 10^{3}\left(\mathrm{~mm}^{2}\right)\right)$ を用いる。

・最適化手法として勾配射影法 ${ }^{12)}$ を用いる。

\section{1 ブレース付き平面骨組モデルの最適解の基本特性}

\subsection{1 ブレース設置スパンの位置による影響}

図 2 のブレース付き平面骨組モデルを考える。層数、スパン数 $(n)$ 、 スパン長 $(l)$ を固定した骨組に対して a ) 〜 c)のようにブレースの位 置を変化させる。層数が 5 層、スパン長 $(l)$ が $7.6 \mathrm{~m} 、$ スパン数 $(n)$ が 6 スパンのブレース付き平面骨組モデルについて、ブレースの位置を 変化させた場合の各部の鋼材量の変化を調べ、その結果を表 1 に示 す。各々の平面骨組モデルに対して、支持する床幅 $6.33 \mathrm{~m}$ として、 鉛直、水平荷重を設定した。



a) 第 1 スパン

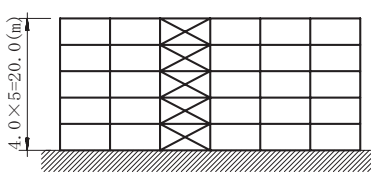

c)第 3 スパン

图 2 ブレースの位置が異なる平面骨組モデルの設定

図 2 に示寸平面骨組において、図の左端のスパンから第 1 スパン、 第 2 スパン、・・、と称することとする。骨組は 6 スパンの対称な モデルであるから、ブレース配置が、第1～第 3 スパンのケースのみ 考慮する。水平荷重の載荷方向は、正負両方向とする。

表 1 ブレースの位置が異なる平面骨組モデルの最適化の結果

\begin{tabular}{|l|c|c|c|c|}
\hline ブレースの位置 & $\begin{array}{c}\text { 梁の鋼材量 } \\
\left(\mathrm{m}^{3}\right)\end{array}$ & $\begin{array}{c}\text { 柱の鋼材量 } \\
\left(\mathrm{m}^{3}\right)\end{array}$ & $\begin{array}{c}\text { ブレース鋼材量 } \\
\left(\mathrm{m}^{3}\right)\end{array}$ & $\begin{array}{c}\text { 総鋼材量 } \\
\left(\mathrm{m}^{3}\right)\end{array}$ \\
\hline a) 第 1 スパン & 1.94 & 1.30 & 0.472 & 3.71 \\
\hline b) 第 2 スパン & 1.94 & 1.30 & 0.461 & 3.71 \\
\hline c) 第 3 スパン & 1.93 & 1.33 & 0.456 & 3.72 \\
\hline
\end{tabular}

表 1 より、各モデルの各部位（梁、柱、ブレース）の最適総鋼材 量や総鋼材量は大きな差がなく、ブレースの位置は最適総鋼材量に ほとんど影響を与えないことが分かる。この結果は、他のモデル $(10$ 層の場合や 4 スパン、8 スパンの場合のブレース付き平面骨組モデ ル）を最適化した結果でも同じであった。従って、本章で扱うブレ 一ス付き平面骨組モデルにおいてはブレースの位置に大きな影響を 受けないと見なし、モデルの分析を行なう。

図 3 は図 2 のモデルの最適化で得られた各部材の断面積を線の太 さで表現したものである。ブレースの位置によらず、各モデルの最 適解の部材断面積はブレースの周りで大きく、他の部材ではほぼ均 等になっている。

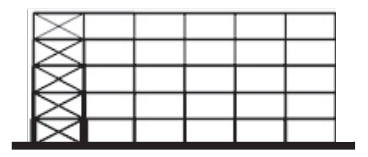

a) 第 1 スパン

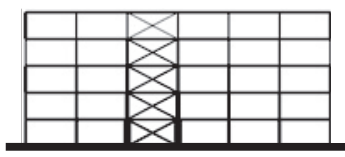

c) 第 3 スパン

図 3 ブレースの位置が異なる平面骨組モデルの断面積の分布

\section{1 .2 ブレース設置スパンの間隔による影響}

図 4 のブレース付き平面骨組モデルを考える。層数、スパン数 $(n) 、$ スパン長 $(l)$ を固定した骨組に対して、設置するブレースのスパン数 が同じ場合に、ブレース設置スパンの間隔の違いが、最適総鋼材量 に及ぼす影響を調べる。図 4 のブレース付き平面骨組モデルに対し て、層数 $\left(N_{H}\right)$ は 5 層、10 層、スパン長 $(l)$ は $8 \mathrm{~m} 、 12 \mathrm{~m} 、$ スパン数 $(n)$ は 15 スパンの場合について、ブレース設置スパンの間隔の変化によ る最適総鋼材量の変化を調べ、その結果を表 2 に示す。各々の平面 骨組モデルに対して、支持する床幅 $6.33 \mathrm{~m}$ として、鉛直、水平荷重 を設定した。

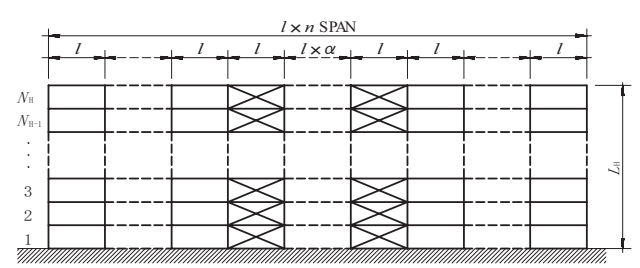

図 4 ブレースの間隔が異なる平面骨組モデルの設定

表 2 より、5 層モデルでは、ブレース設置スパンの間隔によらず、 ほぼ同じ鋼材量となっていることがわかる。しかし、10 層モデルで は間隔が $3 ， 5 ， 7$ スパンの場合の最適総鋼材量はほぼ一致している が、間隔が 1 スパンの場合の最適総鋼材量はそれよりも小さい值と なっている。その理由としては、図 5 より、ブレースが近接してブ レースを中心とした水平力支持区間が重複した場合、ブレース設置 スパン間の梁の断面が大きくなることで水平抵抗力が向上し、鋼材 量の低減効果が生じたと考えられる。この効果は、一般に境界梁効 果としてよく知られている。また、ブレースの水平力支持区間の範 囲は高層モデルになるほど広くなる傾向が見られた。

表 2 各々のモデルに対する最適総鋼材量とブレース鋼材量の比較

\begin{tabular}{|c|c|c|c|c|c|}
\hline \multirow{2}{*}{ 層数 } & \multirow{2}{*}{$\begin{array}{l}\text { ズレース没置 } \\
\text { スパンの粫隔 }\end{array}$} & \multicolumn{2}{|c|}{ ブレースの鋼材量 $\left(\mathrm{m}^{3}\right)$} & \multicolumn{2}{|c|}{ 最適総鋼材量 $\left(\mathrm{m}^{3}\right)$} \\
\hline & & $8 \mathrm{~m}$ & $12 \mathrm{~m}$ & $8 \mathrm{~m}$ & $12 \mathrm{~m}$ \\
\hline \multirow{4}{*}{5 層 } & 1 スパン & 1.27 & 2.23 & 9.82 & 20.79 \\
\hline & 3 スパン & 1.28 & 2.23 & 9.82 & 20.80 \\
\hline & 5 スパン & 1.27 & 2.27 & 9.82 & 20.80 \\
\hline & 7 スパン & 1.28 & 2.24 & 9.83 & 20.81 \\
\hline \multirow{4}{*}{10 層 } & 1 スパン & 4.48 & 8.76 & 29.96 & 57.59 \\
\hline & 3 スパン & 4.08 & 9.54 & 31.50 & 59.03 \\
\hline & 5 スパン & 4.52 & 9.54 & 31.59 & 59.04 \\
\hline & 7 スパン & 4.52 & 9.56 & 31.58 & 59.03 \\
\hline
\end{tabular}




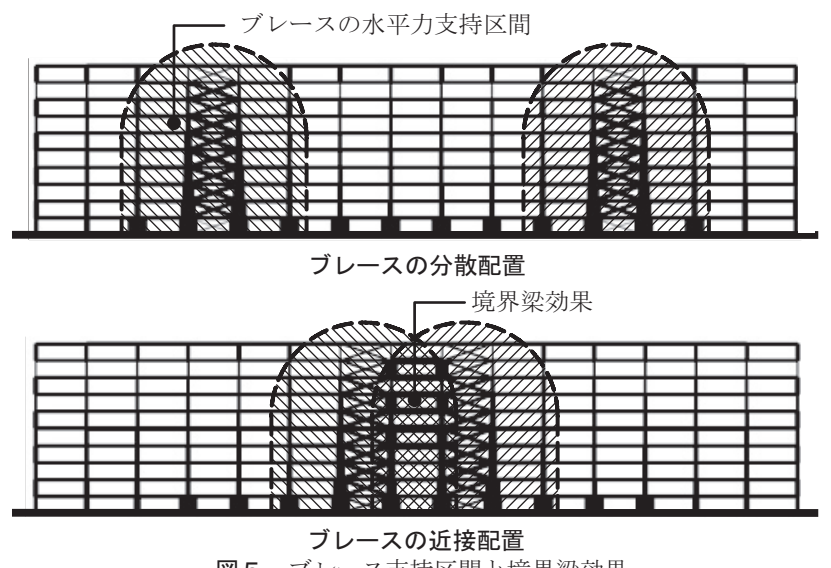

図 5 ブレース支持区間と境界梁効果

また、各モデルのブレースの鋼材量をみると、5 層ではほぼ同じ值

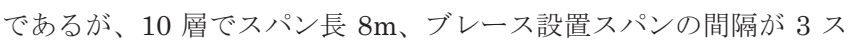
パンのモデルで若干の差がみられる。それは高層であることに起因 するアスペクト比の増加が転倒モーメントの増大に寄与する影響が 考えられる。しかし、ほとんどのモデル（他のスパン長、スパン数 のモデルの解析結果でも）で差はない。

以上の結果より、最適総鋼材量やブレースの鋼材量はお互いのブ レースが十分に離れていればその位置に影響を受けないといえる。

\section{2 ブレース設置スパン数の異なる平面モデルの最適解特性}

\subsection{1 ブレース設置スパン数の異なる平面骨組モデル}

図 6 のブレース付き平面骨組モデルを考える。層数、スパン数 $(n)$ 、 スパン長 $(l)$ を固定した骨組に対してブレースが互いに影響を受け ないように十分に離して配置させた場合、ブレース設置スパン数の 変化による最適総鋼材量の変化を調べる。図 6 のブレース付き平面 骨組モデルに対して、層数 $\left(N_{H}\right)$ が 5 層、スパン長 $(l)$ が $8 \mathrm{~m} 、 12 \mathrm{~m}$ 、 スパン数 $(n)$ が 15 スパンの場合について、ブレース設置スパン数の 変化による最適総鋼材量の変化を調べ、その結果を表 3 に示す。各々 の平面骨組モデルに対して、支持する床幅 $6.33 \mathrm{~m}$ として、鉛直、水 平荷重を設定した。

表 3 にブレース設置スパン数の変化に伴う最適総鋼材量、ブレー スの鋼材量の変化を示す。表 3 に示寸ように、ブレース設置スパン 数の増加に伴い、最適総鋼材量は減少している。その減少の割合は スパン長 $(l)$ が $8 \mathrm{~m}$ より $12 \mathrm{~m}$ でより大きく、スパン長 $(l)$ が長くなる 程ブレースの効率が高くなることが分かる。

しかし、タイプによって最適総鋼材量が異なるのに対して、ブレ
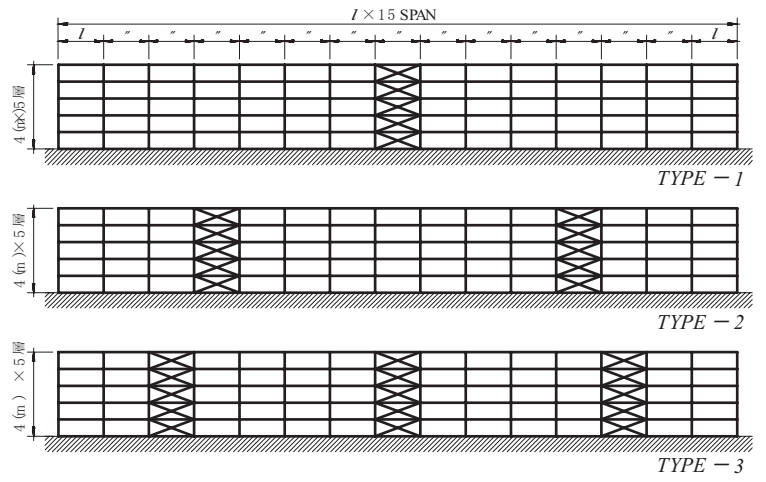

図 6 ブレース設置スパンの数が異なる平面骨組モデル $(n=15)$
表 3 最適総鋼材量とブレースの鋼材量

\begin{tabular}{|c|c|r|c|r|c|}
\hline \multirow{2}{*}{$\begin{array}{c}\text { スパン } \\
\text { 長 }\end{array}$} & \multirow{2}{*}{ TYPE } & \multicolumn{2}{|c|}{ ブレース } & \multicolumn{2}{|c|}{ 全体フレーム } \\
\cline { 2 - 6 } & & 鋼材量 $\left(\mathrm{m}^{3}\right)$ & \multicolumn{1}{c|}{ 比 } & 鋼材量 $\left(\mathrm{m}^{3}\right)$ & 比 \\
\hline \multirow{3}{*}{$8 \mathrm{~m}$} & $\mathrm{TYPE}-1$ & 1.28 & $100.00 \%$ & 9.96 & $100.00 \%$ \\
\cline { 2 - 6 } & $\mathrm{TYPE}-2$ & 1.28 & $100.08 \%$ & 9.83 & $98.68 \%$ \\
\cline { 2 - 6 } & $\mathrm{TYPE}-3$ & 1.28 & $99.92 \%$ & 9.74 & $97.86 \%$ \\
\hline \multirow{3}{*}{$12 \mathrm{~m}$} & $\mathrm{TYPE}-1$ & 4.36 & $100.00 \%$ & 32.56 & $100.00 \%$ \\
\cline { 2 - 7 } & $\mathrm{TYPE}-2$ & 4.52 & $103.62 \%$ & 31.58 & $96.99 \%$ \\
\cline { 2 - 7 } & $\mathrm{TYPE}-3$ & 4.64 & $106.33 \%$ & 31.04 & $95.33 \%$ \\
\hline
\end{tabular}

一スの総鋼材量は変化がなく、ほぼ同じ值を示している。それは同 じ規模のモデルで、ブレースが互いに影響を受けない範囲に配置さ れていれば、ブレース設置スパン数に関わらず、ブレース全体が負 担する水平力が一定であることを意味し、ブレース設置スパン数を 増やしても、骨組の総鋼材量は長期荷重で決まる值以下には低下せ ず、ブレースの総鋼材量も一定であるため、ブレース設置スパン数 を増やすことによる総鋼材量低減効果には限度があると考えられる。 表 3 より、1 ブレース設置スパンあたりの総鋼材量低減効果は、ブ レース設置スパン数の増加に伴って小さくなっていくことが分かる。

\subsection{2 ブレース設置スパンの結合数の異なる平面骨組モデル}

3.2 .1 節の結果より、ブレースを近接して配置させると鋼材量の低 減効果があることが分かった。本節では、連続するブレース配置の スパン数（以下、ブレースの結合数と称する）と最適総鋼材量との 関係について調べる。

図 7 のブレース付き平面骨組モデルを考える。層数、スパン数 $(n) 、$ スパン長 $(l)$ を固定した骨組に対して、ブレースの結合スパン数を 0 スパンから $m$ スパンまで変化させる。その結果から、ブレースの設 置スパンの結合数と最適総鋼材量の関係を調べる。図 7 のブレース 付き平面骨組モデルに対して、層数 $\left(N_{H}\right)$ が 5 層、10 層、スパン長 $(l)$ が $8 \mathrm{~m}$ 、スパン数 $(n)$ が 15 スパンの場合について、ブレースの結合 数による最適総鋼材量の変化を調べ、その結果を表 4 に示す。各々 の平面骨組モデルに対して、支持する床幅 $6.33 \mathrm{~m}$ とて、鉛直、水 平荷重を設定した。

表 4 にブレース設置スパンの結合数 $m$ の変化による最適総鋼材量、 ブレースの鋼材量を示す。表 4 の結果をグラフ化したものを図 8 に
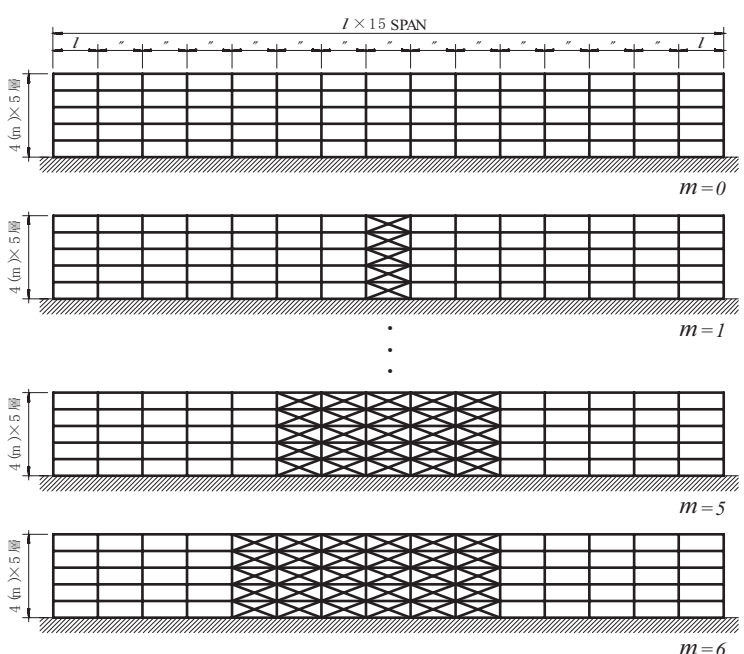

図 7 ブレース設置スパンの結合数の異なる平面骨組モデル $(n=15)$ 
表 4 ブレースの結合数と最適総鋼材量

\begin{tabular}{|c|c|c|c|c|c|c|}
\hline \multirow{2}{*}{$\begin{array}{c}\text { ブレース } \\
\text { 設置 } \\
\text { スパン数 }\end{array}$} & \multicolumn{3}{|c|}{5 層（単位 : $\mathrm{m}^{3}$ ) } & \multicolumn{3}{|c|}{10 層（単位 : $\mathrm{m}^{3}$ ) } \\
\hline & $\begin{array}{c}\text { ブレース } \\
\text { 鋼材量 }\end{array}$ & 総鋼材量 & 比 & $\begin{array}{c}\text { ブレースの } \\
\text { 鋼材量 }\end{array}$ & \begin{tabular}{|c} 
最適総鋼材 \\
量
\end{tabular} & 比 \\
\hline 0 & 0 & 13.41 & $100.00 \%$ & 0 & 39.50 & $100.00 \%$ \\
\hline 1 & 1.28 & 9.96 & $74.26 \%$ & 4.31 & 32.50 & $82.27 \%$ \\
\hline 2 & 1.32 & 9.54 & $71.12 \%$ & 5.68 & 27.92 & $70.67 \%$ \\
\hline 3 & 1.33 & 9.41 & $70.16 \%$ & 5.39 & 26.33 & $66.65 \%$ \\
\hline 4 & 1.32 & 9.34 & $69.66 \%$ & 5.58 & 25.74 & $65.13 \%$ \\
\hline 5 & 1.32 & 9.30 & $69.35 \%$ & 5.58 & 25.65 & $64.92 \%$ \\
\hline 6 & 1.33 & 9.27 & $69.14 \%$ & 5.48 & 25.63 & $64.89 \%$ \\
\hline
\end{tabular}

示す。純ラーメン骨組にブレースを設置することで最適総鋼材量の 大きな低減効果が期待でき、ブレース設置スパンの増加に伴い最適 総鋼材量は減少していることが分かる。図 8 より、最適総鋼材量は ブレースの設置スパンの結合数の増加に連れて減少し、ブレース設 置スパンの結合数が 4 スパン以上では鋼材量の変化はほぼ一定にな っている。1 ブレース設置スパンあたりの総鋼材量低減効果は純ラ 一メン骨組の 1 スパンにブレースを設置したときが最も大きい。 5 層 モデルでは、10 層モデルと比べて、より少ない設置スパン数で低減 効果が一定になっている。

しかし、各モデルの最適総鋼材量に占めるブレース鋼材量はブレ 一スの数が増えたにも関わらずほぼ一定になっている。この結果か ら、最適解においては、モデルの規模が同じであればブレースが負 担する水平力の分担率は一定であるといえる。また、ブレースの導 入によって低減可能な鋼材量にも下限が存在するといえる。しかし、 10 層モデルに対するブレース設置スパン数が 1 の場合、ブレースの 鋼材量は他のモデルに比べて小さい值となっている。その理由とし ては、モデルの規模が大きくなったことにより、ブレース周辺骨組 の断面の上限から、1 スパンで負担できる水平力の限界が決まるた めと考えられる。
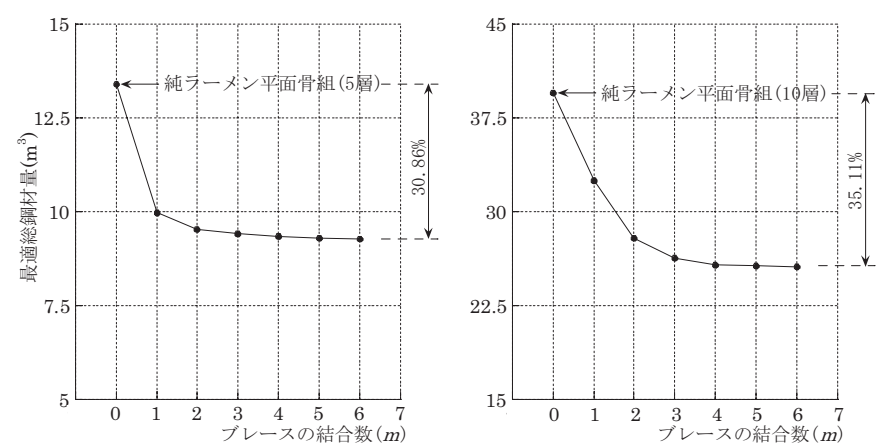

図 8 最適化の結果 (5 層、10 層モデル)

\section{2 .3 結合数の異なる複数のブレース群をもつ平面骨組モデル}

3.3.1 節の結果より、ブレース設置スパンの結合数を増加させても あるスパン数以上になると最適総鋼材量はほぼ一定になることが明 らかになった。その結合された状態を一つのブレース群として考え、 平面モデルの中に結合数の異なる複数のブレース群が配置されてい る場合について、ブレース群と最適総鋼材量との関係を調べる。 図 9 のブレース付き平面骨組モデルを考える。層数、スパン数 $(n) 、$
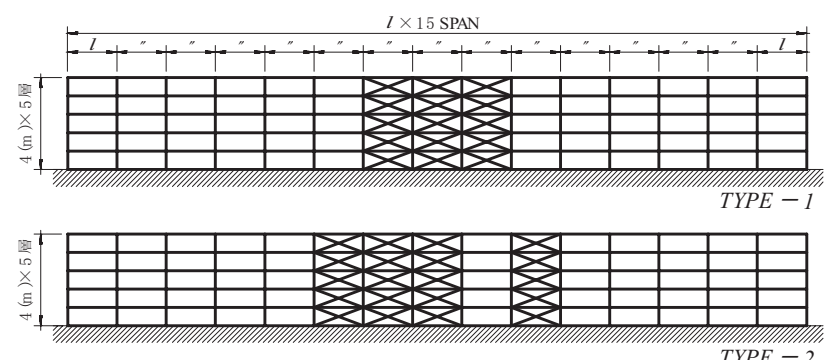

TYPE -2

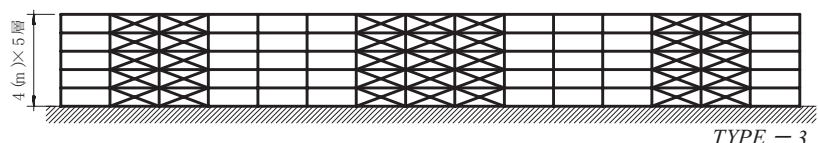

図 9 大きさの異なる複数のブレース群を持つ平面骨組モデル $(n=15)$

スパン長 $(l)$ を固定した骨組に対して、結合数の異なるブレース群を 1 個以上配置させた場合の最適総鋼材量の変化を調べる。図 9 のブレ ース付き平面骨組モデルに対して、層数 $\left(N_{H}\right)$ は 5 層、10 層、スパ ン長 $(l)$ は $8 \mathrm{~m}$ 、スパン数 $(n)$ は 15 スパンの場合について、ブレース 群の数による最適総鋼材量の変化を調べ、その結果を表 5 に示す。 各々の平面骨組モデルに対して、支持する床幅 $6.33 \mathrm{~m}$ として、鉛直・ 水平荷重を設定した。

\begin{tabular}{|c|c|c|c|c|c|c|}
\hline \multirow[b]{2}{*}{ TYPE } & \multicolumn{3}{|c|}{5 層（単位 : $\mathrm{m}^{3}$ ) } & \multicolumn{3}{|c|}{10 層（単位： $\mathrm{m}^{3}$ ) } \\
\hline & $\begin{array}{l}\text { ブレース } \\
\text { の鋼材量 }\end{array}$ & 総鋼材量 & $\begin{array}{l}\text { TYPE }-1 \\
\text { に対する比 }\end{array}$ & $\begin{array}{l}\text { ブレース } \\
\text { の鋼材量 }\end{array}$ & 総鋼材量 & $\begin{array}{l}\text { TYPE-1 } \\
\text { に対する比 }\end{array}$ \\
\hline TYPE -1 & 1.33 & 9.41 & $100.00(\%)$ & 5.39 & 26.33 & $100.00(\%)$ \\
\hline TYPE -2 & 1.33 & 9.41 & $100.00(\%)$ & 5.44 & 26.38 & $100.23(\%)$ \\
\hline TYPE -3 & 1.31 & 9.41 & $100.02(\%)$ & 5.43 & 26.79 & $101.76(\%)$ \\
\hline
\end{tabular}

表 5 に図 9 の複数のブレース群に対する最適総鋼材量、ブレース の鋼材量を示す。TYPE -2 は 3 つのブレースを結合した TYPE-1 の 1 スパン置きにもう 1 スパンのブレース設置スパンがある場合、 TYPE -3 は TYPE- 1 から十分に離れた両端に 2 つのブレースを結 合したブレース群がある場合のブレース付き平面骨組である。

表 5 より、結合数が異なる複数のブレース群を持つ平面モデルは ブレースの数が異なるにも関わらずほぼ同じ最適総鋼材量を示して いる。その理由は、骨組の中でブレースが負担する水平力に対して、 複数の群の中でもっとも低減効果の大きいブレース群がそのほとん どの水平力を負担するのが、鋼材量最小化には最も効率的であると

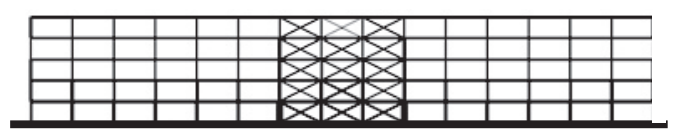

TYPE-1

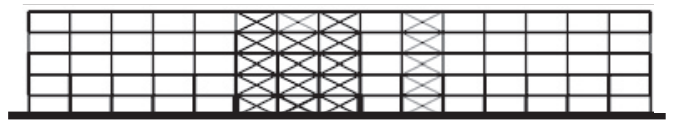

TYPE-2

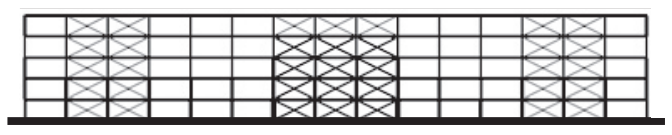

TYPE-3

図 10 平面骨組モデルの断面積の分布 
考えられる。従って、モデルの各部材の断面積の分布においては、 大きな群である 3 つのブレース結合群とその周りの部材の断面積が 大きく、その群から離れた他の部材（梁、柱、ブレース）は均等の 断面積の分布之なっている（図 10）。3つの平面モデルのブレースも ほぼ同じ鋼材量となっている（3.2.1節と同様な結果）。

\section{4. ブレース任意配置問題の最適解予測手法}

\section{1 任意配置ブレースによる低減効果の簡易的評価法}

基本計画段階においてコアの配置を定めることは設計者にとって 最も重要な意思決定の一つである。コアは建物の外観に影響を与え ることなく耐震要素が設置できる数少ない場所の一つであるため、 構造計画的な側面からもより数多くのコアの配置パターンを検討す ることが望ましい。3 節までに得られたブレース配置に関する以下

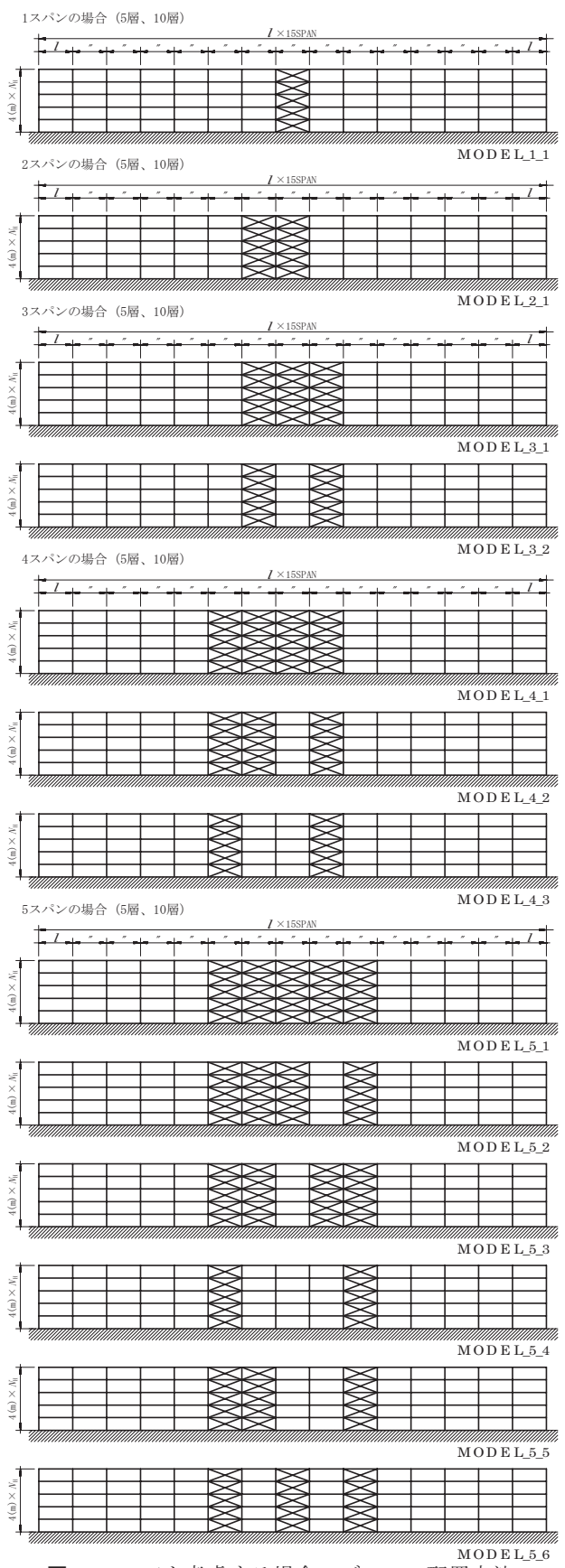

図 11 コアを考慮する場合のブレース配置方法
の知見に基づけば、限定されたモデルの最適解をもとに、任意のブ レース配置による総鋼材量の低減効果を、近似的に評価することが 可能である。

[特性 1]1 スパンにブレースが配置されている場合、その位置に関 わらず最適総鋼材量は同じである。

[特性 2]2 スパン以上にブレースが、互いに十分離れて配置されて いる場合、ブレース設置スパン数が同じであれば、ブレース設置位 置に関わらず最適総鋼材量は同じである。またこの場合、ブレース 設置スパン数の増加に伴って総鋼材量は低減するが、ブレース設置 スパン数がある程度以上増えると一定值に近づく。

[特性 3] ブレースの設置スパンを結合させて配置するほど鋼材量 の大きな低減効果が期待できるが、ブレースの結合数がおおむね 5 スパン程度以上になれば鋼材量は一定值に近づく。

[特性 4] 同じ構面に結合数の異なる複数のブレース群が配置され ている場合、鋼材量の低減効果は、最も結合数の大きなブレース群 によって決定付けられる。

以上の知見を用いると，様々なブレース配置は，[case1]結合数最 大のブレース群が単一の場合, および, [case2]結合数最大のブレー ス群が複数ある場合の 2 つの case に分類することで，ブレース位置 によらず (特性 1), 最適解鋼材量が近似的に評価できることが示唆 される。

[case1] 結合数最大となるブレース群が 1 つしかない場合は, 結 合数最大のブレース群にだけ着目寸ればよく（特性 4), さらに， 5 スパン以上の結合ブレース群は, 5 スパンとみなせばよいことが分か る (特性 3 )。したがって, 結合数最大となるブレース群が 1 つしか ない場合は，5 スパン以下の結合数のブレース群を 1 つだけ配置し

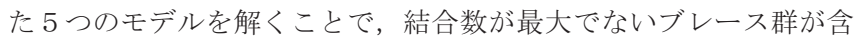
まれる場合の最適鋼材量を予測できることが分かる。

[case2］結合数最大となるブレース群が複数ある場合は, トータ ルのブレーススパン数が 5 を超えると総鋼材量がおおむ称一定とな ることから（特性 $2 、 3$ ）, トータルのブレーススパン数が 5 を超えな い範囲での可能な組み合わせを考えればよいと考えられる。すなわ ち, (1) 1 スパンブレース× 2 箇所, (2) 1 スパンブレース× 3 箇所, (3) 2 スパン結合ブレース $\times 2$ 箇所，の 3 つのモデルを解けばよく，それ を超えるブレース配置については, 総鋼材量は一定とみなすことで 最適鋼材量を予測できることがわかる。

すなわち, [case 1], [case 2]合わせて 8 モデルについて解けばよ いことになる。なお, 上記の解を基準として, 著者らのこれまでの 研究 11)で得られた以下の特性 5), 6) を用いれば, モデルのスパン数 やスパン長が変化した場合の最適解鋼材量も予測することができる。

[特性 5]スパン数と最適総鋼材量は比例関係であり、基準モデルの 鋼材量が分かれば規模の大きいモデルの鋼材量が予測できる ${ }^{11)}$

[特性 6]スパン長と最適総鋼材量は非線形関係である 11)。

\section{2 数值例題}

例題として 5 層モデルを考える。 5 層モデルはブレース配置の影響 を受けるスパンの範囲が狭いことと、特性 3)よりブレースを 5 スパ ン以上結合させても最適総鋼材量の低減効果は得られないことから、 5 スパン以下のブレース配置の組み合わせのパターンを扱う。図 11 は 5 層モデルについて、 5 スパン以内で可能なブレース配置の 13 パ ターンを抽出したものである。スパン数 15 、スパン長 $8 \mathrm{~m}$ の場合に 
おいて、各パターンの最適化の結果を以下に示す。いずれのモデル も、支持する床幅 $6.33 \mathrm{~m}$ として、鉛直、水平荷重を設定した。 MODEL1_1の最適総鋼材量を $100 \%$ として、最適総鋼材量の比率を 比較する (表.5 参照)。

[case1] の結合数最大となるブレース群が 1 つかない場合に対 応して, 次の 5 つのモデルを解く。ブレースの結合数の増加に伴い 最適総鋼材量は減少する。また、結合数が 4 スパン以上になると鋼 材量の変動はほぼ一定になることが確認できる。

MODEL1_1(100.00\%) > MODEL2_1(95.78\%) > MODEL3_1(94.48\%) う MODEL4_1(93.81\%) $\fallingdotseq$ MODEL5_1(93.39\%)

[case2］の結合数最大となるブレース群が複数ある場合に対応し て, 次の 3 つのモデルを解く。ブレースの数の増加に伴い最適総鋼 材量が減少することが確認できる。

MODEL3_2(98.64\%)>MODEL5_6(97.99\%) >MODEL5_3(95.83\%)

上記の 8 モデルに含まれないモデルの最適解鋼材量は，上記の 8 モデルのいずれかとほぼ同じであることが確認できる

・最大結合数が 1 の場合

MODEL4_3(98.66\%) $\fallingdotseq$ MODEL5 $4(98.62 \%) \fallingdotseq M O D E L 3 \_2(98.64 \%)$

・最大結合数が 2 の場合

MODEL2_1(95.48\%) $\fallingdotseq$ MODEL4_2(95.84\%) $\fallingdotseq$ MODEL5_3(95.83\%) $\fallingdotseq$ MODEL5_5(95.91\%)

・最大結合数が 3 の場合

MODEL3_1(94.48\%)门MODEL5_2(94.49\%)

表 5 ブレースの結合数と最適総鋼材量

\begin{tabular}{|c|c|c|c|c|c|c|}
\hline \multirow{2}{*}{ TYPE } & \multicolumn{2}{|c|}{ 最適総鋼材量 } & \multirow{2}{*}{$\begin{array}{c}\text { ブレース } \\
\text { の数 }\end{array}$} & \multirow{2}{*}{$\begin{array}{c}\text { ブレース } \\
\text { の } \\
\text { 結合数 }\end{array}$} & \multirow{2}{*}{$\begin{array}{c}\text { 主な } \\
\text { ブレース } \\
\text { 群=2 }\end{array}$} & \multirow{2}{*}{$\begin{array}{c}\text { 主な } \\
\text { ブレース } \\
\text { 群=3 }\end{array}$} \\
\hline & 鋼材量 $\left(\mathrm{m}^{3}\right)$ & 比 & & & & \\
\hline $11^{*_{1}}$ & 9.96 & $100.00 \%$ & $\bigcirc(1)$ & $\bigcirc(1)$ & & \\
\hline $21^{*_{1}}$ & 9.54 & $95.78 \%$ & & $\bigcirc(2)$ & 0 & \\
\hline $31^{1_{1}}$ & 9.41 & $94.48 \%$ & & $\bigcirc(3)$ & & 0 \\
\hline $3 \_2^{* 2}$ & 9.82 & $98.64 \%$ & $\bigcirc(2)$ & & & \\
\hline $41^{1_{1}}$ & 9.34 & $93.81 \%$ & & $\bigcirc(4)$ & & \\
\hline 4_2 & 9.54 & $95.84 \%$ & & & 0 & \\
\hline $4 \_3$ & 9.82 & $98.66 \%$ & & & & \\
\hline $5 \_1^{* 1}$ & 9.30 & $93.39 \%$ & & $\bigcirc(5)$ & & \\
\hline 5_2 & 9.41 & $94.49 \%$ & & & & 0 \\
\hline $5 \_3^{* 2}$ & 9.54 & $95.83 \%$ & & & 0 & \\
\hline 5_4 & 9.82 & $98.62 \%$ & & & & \\
\hline $5 \_5$ & 9.55 & $95.91 \%$ & & & 0 & \\
\hline $5 \_6^{* 2}$ & 9.76 & $97.99 \%$ & $\bigcirc(3)$ & & & \\
\hline
\end{tabular}

*1,*2 はそれぞれ，4.1節の case1, case2 に対応することを表す

\section{5. まとめ}

本論文では，最適設計を用いて基本計画段階の設計者の意思決定 を支援することを目的とし，基準法上の規定や実務設計で標準的に 用いられている諸条件やモデル化を採用した鋼構造ブレース付き骨 組を対象とし，平面骨組モデルの様々なブレース配置パターンに対 寸る最適解特性の抽出を試みた。得られた成果は以下の通りである。 1) ブレース設置スパン数が同一な平面骨組モデルの最適解の特性を 以下の通り明らかにした。 a. 1 スパンにブレースを配置する場合はその位置に関わらず最適 総鋼材量は同じである。

b. 複数スパンにブレースを配置する場合はブレース同士が互いに 影響しない程度に十分に離れていれば最適総鋼材量・ブレース の鋼材量はブレース配置に関わらず同じである。

2）ブレース設置スパン数が異なる平面骨組モデルの最適解の特性を 以下の通り明らかにした。

a. 同じ規模のモデルの場合、ブレース設置スパン数の増加に伴い、 最適総鋼材量は減少する。しかし、ブレースが互いに影響を受 けない程度に離れて配置されていれば、ブレース設置スパンの 数に関わらず全体のブレースの鋼材量は同一である。

b. 連続するスパンにブレースを配置することで最適総鋼材量の大 きな低減効果が期待できるが、ブレースの結合数がある程度以 上になれば最適総鋼材量はほぼ一定になる。

c. 同じ構面に結合数の異なる複数のブレース群が配置された場合、 骨組の中でブレースが負担寸る水平力に対してもっとも低減 効果の大きいブレース群がそのほとんどの水平力を負担する ため、最適鋼材量は、結合数最大のブレース群に依存して決ま る。

3）任意のブレース配置パターンについて 1)，2）で得られた特性を利 用することで, ブレース配置による総鋼材量の低減効果を, 限定さ れたモデルの最適解に基づいて簡易的に予測する手法を提案した。

以上の方法はマクロな設計問題において純ラーメン骨組にブレー ス配置を考慮するためのコア計画時に有用な情報として用いられる。

\section{参考文献}

1 ）永野康行, 岡本達雄, 辻聖晃, 竹脇出, 上谷宏二：最適設計手法を用いた 実建築骨組の試設計，日本建築学会近畿支部研究報告集，pp. 161 164, 1999.7

2) 永野康行, 岡本達雄, 辻聖晃, 竹脇出, 上谷宏二 : 履歴型ダンパーを有す る実超高層建築物への最適設計手法の適用, 日本建築学会近畿支部研究報 告集，pp. 153〜 156，2000.6

3 ) 辻聖晃 : シンポジウム「創造的な構造設計を支える知恵と技術」, 日本建 築学会近畿支部, pp. $27 \sim 48,2000.11$

4 ) 澤田樹一郎, 中村雄治, 松尾彰 : 指定崩壊機構非形成確率を制約した鋼構 造骨組の最小重量設計, 構造工学論文集, 日本建築学会, Vol. 45B, pp. 259 〜264, 1999.3

5 ）松本慎也，荒井宏，春日康博，平田裕一，山本憲司，藤井大地，藤谷義信 鉄骨骨組構造の最小重量設計における局所解の一例，構造工学論文集，日 本建築学会，Vol. 45B，pp. 249 258，1999.3

6 ) 宗本順三 : 設計の思考とデザインの解, 建築雑誌, 日本建築学会, pp. 30 $\sim 31,2004.11$

7 ) 松下大輔, 宗本順三, 岩田伸一郎: ホテルの客室部分構成比と各事業主体 の NPV 最大化の二目的問題，日本建築学会計画系論文集，第 539 号, pp.139 145, 2001.1

8 ）李有震，吉富信太，上谷宏二 : 鋼構造平面骨組モデルの最適解の特性を用 いた構造計画に関する研究，構造工学論文集，日本建築学会，Vol. 50B, pp. 215 220，2004.4

9 ) 李有震, 吉富信太, 上谷宏二 : 鋼構造平面骨組モデルの最適解を用いた鋼 構造立体骨組モデルの最適解の簡易予測法，日本建築学会大会学術講演梗 概集 (北海道)，pp. 323 324，2004.8

10）李有震，吉富信太，上谷宏二：平面骨組最適解を用いた鋼構造純ラーメン 立体骨組の最適総鋼材量近似予測法，日本建築学会構造系論文集，第 595 号, pp. $65 \sim 71,2005.9$

11）李有震，吉富信太，上谷宏二 : 鋼構造ブレース付き平面骨組モデルのスパ ン割りの変化に対する最適化特性, 日本建築学会構造系論文集, 第 607 号, pp. 95 100，2006.9

12 ) Rosen, J.B. : The Gradient Projection Method for Nonlinear Programming -Part I:Nonlinear Constraints, SIAM J., 9, pp. 514 532, 1961.12 